\title{
Optimized Western Blotting Exploration of H3K27 Methylation Changes under Waterlogging in Barley
}

\author{
Rong Wang ${ }^{1,2}$, Fei Yang ${ }^{3}$, Bo $\mathrm{Li}^{1,2}$, Xiaoyan Wang ${ }^{1,2}$, Wenying Zhang ${ }^{1,2}$ and Yanhao $\mathrm{Xu}^{1,2^{*}}$ \\ ${ }^{1}$ Hubei Key Laboratory of Waterlogging Disaster and Agriculture Use of Wetland \& Engineering Research Center of Ecology \\ and Agriculture Use of Wetland, Ministry of Education, Yangtze University, Jingzhou, Hubei 434025, China \\ ${ }^{2}$ Hubei Collaborative Innovation Center for Grain Industry/College of Agriculture, Yangtze University; Jingzhou, Hubei \\ 434025, China \\ ${ }^{3}$ Department of Genetics and Cell Biology, Yangtze University, Jingzhou, Hubei 434023, China \\ "For correspondence: xyh09@yangtzeu.edu.cn
}

\begin{abstract}
Western blotting is a powerful tool for assessing the presence and modification of a protein. No suitable reference proteins for barley (Hordeum vulgare L.) western blotting has identified. In this study, we compared the quality of the total protein extracted from barley leaves, roots, and seeds using the Tris, QB, direct, phenol, TCA and modified TCA methods. The results confirmed the Tris, direct and modified TCA methods were optimal for seeds, young tissues and mature tissues protein extracting, respectively. The stability and sensitivity among the three reference proteins, i.e., plant actin, heat shock protein 90 , and histone H3, during barley western blotting among were compared in different tissues/organs at various stages of development and/or stress. The results showed that plant actin was the most sensitive and the most constantly expressed among all the reference proteins tested in all barley organs. A linear relationship $(\mathrm{R}=0.9710)$ of the plant actin signal intensity with the sample amount was detected when the total protein ranged within 10-160 $\mu \mathrm{g}$. The optimized barley western blotting procedure was used to investigate the response of H3K27me1 and H3K27me3 to waterlogging in barley. Under waterlogging, the expression of H3K27me1 was repressed in the stems but promoted in the roots, while the expression of $\mathrm{H} 3 \mathrm{~K} 27 \mathrm{me} 3$ was repressed in both the leaf and stem. This is the first report about H3K27 methylation modifications displayed the organspecific response patterns to waterlogging in barley. ( 2018 Friends Science Publishers
\end{abstract}

Keywords: Barley; Western blotting; Reference protein; Histone modification; Waterlogging

\section{Introduction}

Barley (Hordeum vulgare L.), which is one of the most ancient crops, is the fourth most widely cultivated grain crop globally and the oldest natural research material used in classic cytology and genetic studies (Jakob et al., 2014; Langridge, 2014; Lai et al., 2017). Barley is closely related to wheat, and its genetic transition system is relatively widespread; thus, it plays an important role in functional genomics research in Triticeae crops (Mascher et al., 2013; Blake et al., 2016; Mascher et al., 2017). Functional genomics, complemented by whole genome sequencing (Mascher et al., 2017), could provide better insights regarding barley.

Western blotting is an important tool for both protein functional determination and proteomics studies (Hughes $e t$ al., 2014; Wu et al., 2014) and also is a vital tool in histone modification research (Yang et al., 2010; Egelhofer et al., 2011). A standardized protein extraction method and a stably expressed internal reference are necessary for obtaining reliable results in western blotting (Eaton et al., 2014; Wiśniewski and Mann, 2016; Bass et al., 2017). High quality and high purity of total protein are essential criteria for western blotting analysis (Ghosh et al., 2014; Wu et al., 2014; Wiśniewski and Mann, 2016). The same protein extraction method may have different effects in different organs (Saravanan and Rose, 2004; Abdullah et al., 2017). Likewise, the quality of the total protein extracted from the same plant organ using different methods may differ to a certain extent (Saravanan and Rose, 2004; Abdullah et al., 2017). Although research studies have extracted protein from barley, these studies have mainly relied on twodimensional gel electrophoresis (Vítámvás et al., 2015; Guo et al., 2016). Moreover, these reported methods are costly and time-consuming (Ghosh et al., 2014; Wu et al., 2014), easy and stable protein extraction methods for western blotting remain unexplored in barley.

The use of an internal reference protein is essential for the pricise detection of expression levels, and the optimal internal reference protein, which is stably expressed in different tissues and cells, depends on the cell cycle (Wu et al., 2014; Chen and Xu, 2015; Goasdoue et al., 2016). In rice, heat shock protein 90 (HSP 90) and glyceraldehyde3 -phosphate dehydrogenase (GAPDH) are commonly used

To cite this paper: Wang, R., F. Yang, B. Li, X. Wang, W. Zhang and Y. Xu, 2018. Optimized western blotting exploration of H3K27 methylation changes under waterlogging in barley. Int. J. Agric. Biol., 20: 609-616 
internal reference proteins in western blotting (Li et al., 2011), but no internal reference protein is appropriate for all conditions in a western blotting system (Li et al., 2011; Wu et al., 2014; Bell, 2016). Similar to studies in rice (Li et al., 2011), studies using western blotting in barley must be performed using stable, easy protein extraction methods and a valid internal reference protein to obtain reliable and standardized western blotting results. To date, no published study has identified and systematically validated reference proteins suitable for the investigation of barley protein expression.

Waterlogging is a severe abiotic stress that occurs during barley production worldwide, which may resulted in up to $50 \%$ yield loss (Setter and Waters, 2003; de San Celedonio et al., 2014; Zhang et al., 2017). Previous studies have indicated that aerenchyma formation is one of the most effective mechanisms to overcome waterlogging stress (Zhou, 2011; Zhang et al., 2015; Zhang et al., 2017). Quantitative trait loci (QTL) associated with tolerance to waterlogging in barley have been identified in many studies (Zhou, 2011; Zhang et al., 2015, 2017). Epigenetics, particularly histone modifications, play a significant role in the adaptation of plants to environmental stress (Kinoshita and Seki, 2014; Van Oosten et al., 2014; Pan et al., 2014; Pandey et al., 2016; Lämke and Bäurle 2017). The histone H3-Lys4 (H3K4) methylation modification in rice has improved its adaptation to waterlogging stress (Tsuji et al., 2006). However, the histone modification in response to waterlogging in barley is poorly understood.

The aims of this study were try to establish easy and reliable procedures for western blotting in barley and to explore histone methylation changes under waterlogging in barley. For the purposes of this study, 6 protein extraction methods were compared for protein extraction efficiency and effectiveness. And the expression stability and sensitivity of the three reference proteins were compared in different barley tissues/organs to select suitable reference protein. $\mathrm{H} 3 \mathrm{~K} 27 \mathrm{me} 1$ and $\mathrm{H} 3 \mathrm{~K} 27 \mathrm{me} 3$ expression level in stem and root were investigated by the optimized western blotting procedures. The above results provided a new system and tools for epigenetics research in barley under stress.

\section{Materials and Methods}

\section{Plant Materials}

The barley variety used in this study was the Epi No. 2 (Hordeum Vulgare L. cv. Epi No. 2), which is an elite variety in high rainfall regions of Yangtze River basin. Seeds were sown on the $3^{\text {rd }}$ of November in 2014 in experimental fields at the Yangtze University and were managed according to regular standards. The leaves and stems were collected during the seedling stage on the 1st of December in 2014; the young ears and roots were collected on the $21^{\text {st }}$ of March in 2015; and the flag leaf, peduncle and immature seeds were collected on the $19^{\text {th }}$ of April in 2015 .
All samples were preserved in liquid nitrogen and then stored at $-80^{\circ} \mathrm{C}$.

\section{Waterlogging Treatment}

The control and waterlogging treatments were established using an artificial climate chamber (JYC-412, JIAYU, SHANGHAI CHINA). Seeds were sowed and germinated in a pot $(22 \times 20 \mathrm{~cm})$ containing $3.5 \mathrm{~kg}$ of soil and $10 \mathrm{~g}$ of compound fertilizer. Ten similarly young plants were reserved in each pot before treatment. Each treatment involved 4 pots in the chamber $\left(22^{\circ} \mathrm{C} / 15^{\circ} \mathrm{C}\right.$ day/night, 15000 LUX, $18 \mathrm{~h} / 6 \mathrm{~h}$ day/night). The waterlogging treatment was performed 20 days after seeding and lasted for 10 days by putting the plot into the plastic bucket $(30 \times 35 \mathrm{~cm})$. The water level was $3 \mathrm{~cm}$ higher than the soil surface. Three biological replicates were performed under the above mentioned conditions. The samples were collected at fixed times, frozen in liquid nitrogen, and stored at $-80^{\circ} \mathrm{C}$ until further use.

\section{Tris Solvent Based Protein Extraction}

The plant tissue $(1 \mathrm{~g})$ was ground in liquid nitrogen and then homogenized in $2 \mathrm{~mL}$ of lysis buffer A (Table 1). The homogenized samples were centrifuged at $15000 \mathrm{rpm}$ for 30 min at $4^{\circ} \mathrm{C}^{\circ} \mathrm{C}$ after splitting on ice for $30 \mathrm{~min}$. The upper phase was the extraction phase containing the protein.

\section{QB Solvent Based Protein Extraction}

The QB method was modified according to the previous described method (Ni et al., 1996). The plant tissue (1 g) was ground in liquid nitrogen and, then homogenized in 2 $\mathrm{mL}$ of lysis buffer B (4 mL for mature tissues) (Table 1). The homogenized samples were centrifuged at $15000 \mathrm{rpm}$ for $30 \mathrm{~min}$ at $4^{\circ} \mathrm{C}$ after splitting on ice for $30 \mathrm{~min}$. The upper phase was the extraction phase containing the protein.

\section{Direct Protein Extraction Method}

The plant tissue $(1 \mathrm{~g})$ was homogenized in $2 \mathrm{~mL}$ of lysis buffer $\mathrm{C}$ ( $4 \mathrm{~mL}$ for mature tissues) on ice and split for several minutes. The homogenized samples were centrifuged at $15000 \mathrm{rpm}$ for $30 \mathrm{~min}$ at $4^{\circ} \mathrm{C}$. The upper phase was the extraction phase containing the protein. The samples were centrifuged once more under the same conditions before performing the electrophoresis.

\section{Phenol Method}

This method was modified according to the method proposed by Hurkman and Tanaka (1986). The plant tissue $(1 \mathrm{~g})$ was ground in liquid nitrogen and then homogenized in $4 \mathrm{~mL}$ of extraction buffer $\mathrm{A}$ ( $8 \mathrm{~mL}$ for mature tissue). The homogenized samples were centrifuged at $15000 \mathrm{rpm}$ for 10 
$\min$ at $4^{\circ} \mathrm{C}$. The upper phase was transferred to a new tube. An equal volume of Tris-saturated phenol ( $\mathrm{pH}$ 8.0) was added, mixed vigorously, and then centrifuged at $15000 \mathrm{rpm}$ for $10 \mathrm{~min}$ at $4^{\circ} \mathrm{C}$. Then, 5 times the volume of $0.1 \mathrm{M}$ acetate (methyl alcohol as the solvent) of the phenol phase was added. The samples were centrifuged at $15000 \mathrm{rpm}$ for $10 \mathrm{~min}$ at $4^{\circ} \mathrm{C}$ after precipitation for over $1 \mathrm{~h}$ at $-20^{\circ} \mathrm{C}$. The supernatant was discarded, and the precipitate was washed thrice with cold acetone and then vacuum dried for $5 \mathrm{~min}$. The dried powder was dissolved in $1 \mathrm{~mL}$ of lysis buffer A per $30 \mathrm{mg}$. After the protein powder was completely dissolved, the supernatant was extracted with the protein after centrifugation at $15000 \mathrm{rpm}$ for $15 \mathrm{~min}$ at $4^{\circ} \mathrm{C}$.

\section{TCA Acetone Precipitation Method}

This method was modified according to the previous proposed method (Wang et al., 2006). The plant tissue (0.5 g) was ground in liquid nitrogen and then homogenized in 5 $\mathrm{mL}$ of $10 \%$ TCA (acetone was used as the solvent). The mixture was precipitated for over $1 \mathrm{~h}$ at $-20^{\circ} \mathrm{C}$ and centrifuged at $15000 \mathrm{rpm}$ for $15 \mathrm{~min}$ at $4^{\circ} \mathrm{C}$. The supernatant was discarded, and the precipitate was washed with cold acetone until it was clear and then vacuum dried for $5 \mathrm{~min}$. The dried powder was dissolved in $1 \mathrm{~mL}$ of lysis buffer A per $30 \mathrm{mg}$. After the protein powder was completely dissolved, the samples were centrifuged at $15000 \mathrm{rpm}$ for 15 $\min$ at $4^{\circ} \mathrm{C}$ to obtain the supernatant with the protein.

\section{Modified TCA Method}

The plant tissue $(0.5 \mathrm{~g})$ was ground in liquid nitrogen, homogenized in $2 \mathrm{~mL}$ of lysis buffer $\mathrm{A}$ ( $4 \mathrm{~mL}$ for mature tissue), and centrifuged at $15000 \mathrm{rpm}$ for $15 \mathrm{~min}$ at $4^{\circ} \mathrm{C}$. The precipitate was discarded, and the supernatant was added to $50 \%$ TCA (water was used as the solvent) until the final concentration of TCA was $10 \%$. The samples were precipitated on ice for $30 \mathrm{~min}$ and centrifuged at $15000 \mathrm{rpm}$ for $30 \mathrm{~min}$ at $4^{\circ} \mathrm{C}$. The supernatant was discarded, and the precipitate was washed using ice cold acetone thrice until it was clear. The precipitate was vacuum dried for $5 \mathrm{~min}$. The dried powder was dissolved in $1 \mathrm{~mL}$ of lysis buffer A per 30 $\mathrm{mg}$. After the protein powder was completely dissolved, the supernatant was extracted with the protein after centrifugation at $15000 \mathrm{rpm}$ for $15 \mathrm{~min}$ at $4^{\circ} \mathrm{C}$.

\section{Measurement of the Protein Concentration}

The protein concentration was measured on a Multi-Mode Microplate Readers (BioTek Synergy 2) using the BCA protein assay kit (BIYUNTIAN P0012). BSA (5 mg/mL BSA, BIYUNTIAN P0007) was used as the standard protein, and the procedure was performed according to the manufacturer's instructions.

\section{SDS-PAGE Electrophoresis and Staining}

The gels used in polyacrylamide gel electrophoresis (SDS-PAGE) consisted of 2 parts: stock gel (5\%) and spacer gel (12\%). The SDS-PAGE electrophoresis was carried out in electrophoresis buffer $(25 \mathrm{mmol} / \mathrm{l}$ Tris-base, $25 \mathrm{mmol} / \mathrm{l}$ glycine solution, and $0.1 \% \mathrm{SDS}$ ); the first cycle was set at $40 \mathrm{~V}$ per gel for $30 \mathrm{~min}$, and the second cycle was set at $60 \mathrm{~V}$ per gel for $50 \mathrm{~min}$. Then, the gels were stained with the Coomassie Blue staining solution (1 g/L Coomassie R250, $45 \%$ alcohol, and $10 \%$ acetic acid) for $1 \mathrm{~h}$ at a normal temperature. Then, the gels were washed with a bleaching solution (10\% alcohol and $10 \%$ acetic acid) until the solution was clear. The results were recorded using the Syngene (G:BOX CHEMI XRQ) system.

\section{Western Blotting}

All antibodies used in this study are listed in Table 2. A wet-gel transfer system was used in this study. From the negative electrode to the positive electrode, the cell layer contained a sponge filter paper-page gel-PVDF membrane-sponge (MILIBO IPVH00010). The western blotting was performed in transfer buffer (48 mmol/1 Trisbase, $39 \mathrm{mmol} / \mathrm{l}$ glycine, and $0.037 \% \mathrm{SDS}$ ) at $200 \mathrm{~mA}$ (120 $\mathrm{min}$ ) at $4^{\circ} \mathrm{C}$, followed by blocking the PVDF membrane in fat-free milk $(5 \%)$ for $1.5 \mathrm{~h}$. After washing for $10 \mathrm{~min}$ with TBST, the PVDF membrane was incubated with the diluted primary antibody overnight at $4^{\circ} \mathrm{C}$. After 5 washes ( 5 min per wash) with TBST, the membrane was incubated with the secondary antibody for $1.5 \mathrm{~h}$ at $36^{\circ} \mathrm{C}$, washed 4 times (10 min per wash), and dyed using the ECL detection reagent (Bio-Rad 1705060), and the signal was captured using the Syngene (G: BOX-CHEMI-XRQ) system.

\section{Data Analysis}

Three technical replicates has been performed for protein extracting and reference protein comparison. The GeneTools software (Syngene) was used in this research to analyse the gel bands after Coomassie staining to identify the differences in the quality among the 6 protein extraction methods. The captured western blotting signals were digitized into grey value using the GeneTools software. The relative expression levels (target protein signal grey value/internal reference protein signal grey value) were used to assess the signal intensities of the target proteins. The box plot analysis and coefficient of variation analysis were used to compare the expression sensitivity and stability of the internal reference protein. All statistical analyses were performed using SPSS 19.0 for windows and Micoral originpro 8.5. 
Table 1: Lysis buffer composition for protein extraction

\begin{tabular}{ll}
\hline Lysis Buffer & Components and Concentrations \\
\hline Lysis buffer A & $8 \mathrm{M}$ Urea, 660 mM Tris-HCl, 2\% SDS, 1 mM DTT, 1 mM PMSF \\
Lysis buffer B & $1 \mathrm{mM} \mathrm{KPO}, 1 \%$ TritonX-100, 10\% Gly, 1 mM DTT, 1 mM PMSF \\
Lysis buffer C & $8 \mathrm{M}$ Urea, 4\% Triton X-100, $5 \%$-Me, 5\% PVP-40, $1 \mathrm{mM}$ DTT, $1 \mathrm{mM}$ PMSF \\
Extract buffer A & 0.7 M Sucrose, $0.5 \mathrm{M}$ Tris-HCl, 30 mM HCl, 50 mM EDTA, 0.1 M KCl, 2\% SDS, 1 mM DTT, 1 mM PMSF \\
\hline
\end{tabular}

Table 2: Antibodies and concentrations used in this study

\begin{tabular}{llll}
\hline Antibody & Manufacturer & ID & Dilution ratio \\
\hline Anti-plant Actin Mouse & Abbkine & A01050 & $1: 4000$ \\
Anti-histone H3 Rabbit & PL laboratories & PL030349R & $3: 1000$ \\
Anti-HSP 90 Rabbit & Beijing Protein Innovation & AbM51099-31-pu & $1: 3000$ \\
Anti-H3K27me3 Rabbit & MILLIPORE & $07-449$ & $1: 500$ \\
Anti-H3K27me1 Rabbit & MILLIPORE & $07-448$ & $1: 500$ \\
Gout anti Mouse IgG/IgM HRP & MILLIPORE & AP130P & $1: 10000$ \\
Anti-IgG FC Rabbit & MILLIPORE & AP132F & $1: 10000$ \\
\hline
\end{tabular}

Table 3: Comparison of the 6 total protein extraction methods

\begin{tabular}{|c|c|c|c|c|c|c|c|}
\hline & \multirow[t]{2}{*}{ Organ } & \multicolumn{6}{|c|}{ Methods } \\
\hline & & Tris & QB & Direct & Phenol & TCA & Modified TCA \\
\hline Time (min) & & 70 & 45 & 70 & 200 & 170 & 170 \\
\hline \multirow[t]{3}{*}{ Concentration $(\mu \mathrm{g} / \mu \mathrm{l}) *$} & Root & $2.3 \pm 0.2 \mathrm{~h}$ & $1.3 \pm 0.2 \mathrm{~cd}$ & $2.3 \pm 0.2 \mathrm{~h}$ & $4.1 \pm 0.1 \mathrm{~g}$ & $3.9 \pm 0.2 \mathrm{~g}$ & $3.9 \pm 0.1 \mathrm{~g}$ \\
\hline & Leaf & $9.2 \pm 0.2 b$ & $4.8 \pm 0.2 \mathrm{f}$ & $8.9 \pm 0.4 b$ & $8.9 \pm 0.2 b$ & $7.0 \pm 0.2 \mathrm{~cd}$ & $5.6 \pm 0.2 \mathrm{e}$ \\
\hline & Seed & $37.0 \pm 1 \mathrm{a}$ & $7.0 \pm 0.1 \mathrm{~d}$ & $7.5 \pm 0.2 \mathrm{c}$ & $4.0 \pm 0.1 \mathrm{~g}$ & $7.1 \pm 0.2 \mathrm{~h}$ & $7.1 \pm 0.1 \mathrm{~cd}$ \\
\hline \multirow[t]{2}{*}{ No. of bands } & Root & 9 & 3 & 11 & 21 & 14 & 13 \\
\hline & Leaf & 20 & 17 & 22 & 24 & 24 & 24 \\
\hline \multirow[t]{3}{*}{ Range of molecular weight (KDa) } & Root & $13-53$ & --- & $15-51$ & $14-116$ & $16-91$ & $14-90$ \\
\hline & Leaf & $13-97$ & $13-88$ & $14-92$ & $14-99$ & 14-103 & 14-105 \\
\hline & Seed & $13-114$ & $14-96$ & $17-85$ & $17-85$ & $16-94$ & $15-75$ \\
\hline
\end{tabular}

*: Different letters behind the number represent significant differences at 0.05 level

\section{Results}

\section{Comparison of the Different Protein Extraction Methods}

Six different protein extraction methods were used to extract total protein from young leaves, roots and mature seeds. The extraction efficiencies of the different methods were compared. In the young leaf tissue, the lowest protein concentration $(4.8 \pm 0.2 \mu \mathrm{g} / \mu \mathrm{L})$ was obtained using the QB method. No significant differences were found for leaf protein extraction among the Tris, direct and phenol extraction methods (Table 3). In the root tissue, the concentrations obtained using the QB and direct methods were markedly lower than those observed using the phenol method, TCA method and modified TCA method. The lowest concentration $(1.3 \pm 0.2 \mu \mathrm{g} / \mu \mathrm{L})$ was obtained using the QB method, while the highest concentration $(4.1 \pm 0.1$ $\mu \mathrm{g} / \mu \mathrm{L}$ ) was obtained using the phenol method (Table 3). In the mature seeds, the Tris method extracted protein at a markedly higher concentration $(37.0 \pm 1 \mu \mathrm{g} / \mu \mathrm{L})$ than the other 5 methods.

To compare the differences in the bands extracted by the 6 methods, the total proteins extracted from the leaf (Fig. 1a), root (Fig. 1b) and seed (Fig. 1c) tissues were separated by SDS-PAGE electrophoresis and stained by Coomassie. The results were recorded in GeneTools (SYNGENE).
Regarding the total protein extracted from the barley leaves, the protein bands at $65-100 \mathrm{kDa}$ were absent when using the Tris, QB and direct methods but were detected when using the phenol, TCA and modified TCA methods (Table 3). Regarding the total protein extracted from the barley root, the phenol method isolated the protein bands that at $14-116 \mathrm{kDa}$, while the protein bands that at $90-116 \mathrm{kDa}$ were absent when using the TCA and modified TCA methods; moreover, the bands at $60-116 \mathrm{kDa}$ were absent when using the Tris, QB or direct methods. Regarding the total protein extracted from the barley seeds, the Tris method produced the highest number of bands; however, the protein bands obtained using the phenol, TCA and modified TCA methods were much clearer than those obtained using the Tris method (Fig. 1c). In general, the phenol method was superior for extracting large molecular weight proteins, followed by the TCA and modified TCA methods.

\section{Comparison of the Stability of the Internal Reference Proteins in Barley}

The total protein from root and mature tissues was isolated using the modified TCA method. The total protein from the young tissues and immature seeds was isolated using the direct method. Moreover, the total protein from the mature seed was isolated using the Tris method. 


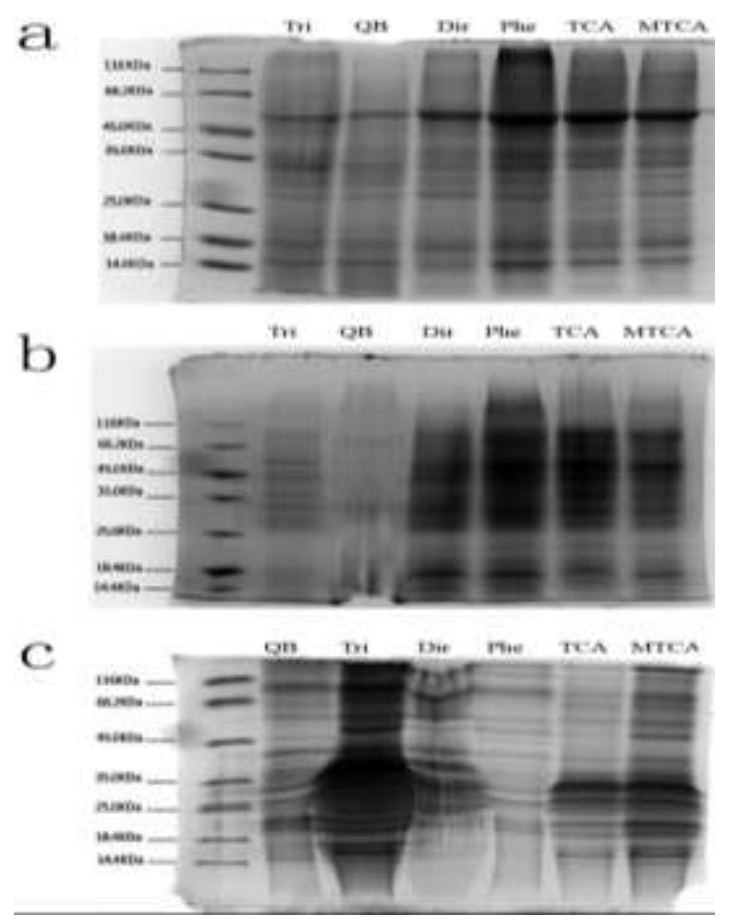

Fig. 1: SDS-PAGE electrophoretic separation of proteins extracted from the leaves, roots and mature seeds using different protein extraction methods. (a) SDS-PAGE results using different extraction methods from barley leaves. (b) SDS-PAGE results using different extraction methods from barley roots. (c) SDS-PAGE results using different extraction methods from barley mature seeds. Tri: Tris extraction method; QB: QB extraction method; Dir: Direct extraction method; Phe: Phenol extraction method; TCA: acetone precipitation method; MTCA: Modified TCA method

For each sample, $80 \mu \mathrm{g}$ of protein was used for the western blotting analysis. The internal reference proteins plant actin, histone H3 and HSP 90 (Fig. 2a) hybridized with the target organs in barley and were expressed stably. Furthermore, we identified the expression levels of these 3 internal reference proteins in the roots, stems and leaves under waterlogging and normal conditions (Fig. 2a). The box plot analysis indicated that the expression of plant actin is much more stable that the other 2 internal reference proteins (Fig. 2b). The coefficients of variation for plant actin, histone H3 and HSP 90 were 0.1037, 0.5818, and 0.2866 , respectively. Thus, histone $\mathrm{H} 3$ is much more variable in different barley tissues/organs at different developmental/stress stages in barley.

\section{Comparison of the Sensitivities among the Reference Proteins in Barley}

The sensitivities of the three tested proteins were compared using gradient western blotting. The total protein sample which was extracted from the mature barley seeds was used,

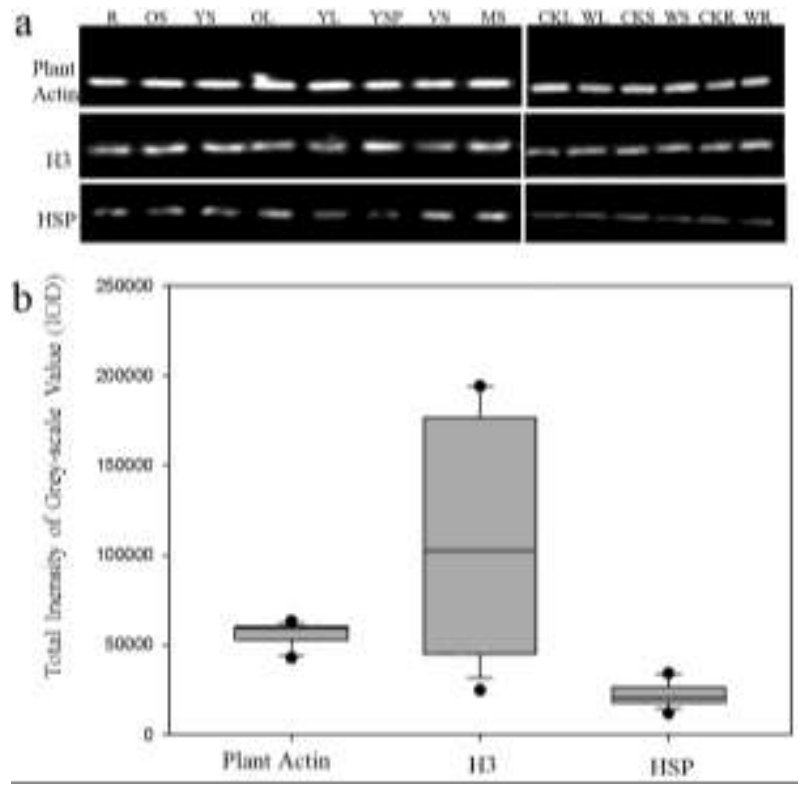

Fig. 2: Expression and box plot analysis of the 3 internal reference proteins in target organs in barley. (a) Expression of 3 internal reference proteins in the target organs. (b) Box plot analysis of the signal intensities in the target organs. R: root; OS: old stem; OL: old leaf; YS: young leaf; YSP: young spider; US: immature seed; MS: mature seed; CKL: control leaf; WL: waterlogging leaf; CKS: control stem; WS: waterlogging stem; CKR: waterlogging root; WR: waterlogging root

and the gradient for the total protein amount was set as 0,1 , 2, 4, 10, 20, 40, 80, 160 and $200 \mu \mathrm{g}$. The results (Fig. 3a) showed that all three target proteins displayed a western blotting signal within a reasonable range. The signal intensities of all three candidate reference proteins increased as the total loaded protein amount increased. Plant actin yielded a significant signal with $1 \mu \mathrm{g}$ of total protein, while histone H3 and HSP 90 only showed a detectable signal at $10 \mu \mathrm{g}$ and above.

The quantification analyses showed that the signal intensity of plant actin increased in a logarithmic manner as the loading amount of total protein increased (Fig. 3b). Its sensitivity in the $1-10 \mu \mathrm{g}$ range was relatively low. No significant change was observed. However, its signal intensity increased exponentially as the quantity of the total protein increased in the $10-160 \mu \mathrm{g}$ range. The signal intensity tended to saturate at protein concentrations of $160 \mu \mathrm{g}$ or greater. The linear relationship between the signal intensity and the sample quantity was assessed for the three candidate proteins in the 10-160 $\mu \mathrm{g}$ range. Both histone $\mathrm{H} 3$ and plant actin displayed a linear relationship between the signal intensity and loading amount, with $\mathrm{R}$ values of 0.9902 and 0.9710 , respectively. The linear relationship for HSP 90 was not significant. 
Effects of Waterlogging on the Methylation of H3K27 in Barley

Plant actin was used as the reference protein to assess the effects of waterlogging on the alterations in the methylation of histone $\mathrm{H} 3$ at lysine 27 (H3K27me1 and H3K27me3) (Fig. 4a). The relative expression level analysis showed that H3K27me1 remained stable (relative expression levels of 1.15 and 1.17) in the leaf tissue under waterlogging stress conditions (Fig. 4b). H3K27me1 declined significantly $(1.37 / 0.62)$ in the shoot tissues under waterlogging conditions. However, its expression increased significantly $(0.58 / 0.95)$ in the root tissues. In contrast, H3K27me3 decreased significantly in both the leaf (1.34/1.04) and shoot $(0.98 / 0.64)$ tissues under the waterlogging stress conditions. H3K27me3 showed no significant changes $(0.72 / 0.71)$ in the root tissues under the waterlogging conditions. Altogether, our results indicated that covalent histone modifications such as methylation display tissue specificity in barley subjected to waterlogging stress.

\section{Discussion}

\section{Optimal Protein Extraction Methods for Different Barley Organs}

The extraction efficiency and effectiveness of various extraction methods in terms of the total protein extracted from different organs in barley is obscure. Therefore, we compared and evaluated the differences in the quality of the total protein extracted from barley leaves, roots, and seeds using the Tris, QB, direct, phenol, TCA and modified TCA methods. The QB method was the most efficient way regarding the extraction time, while the quality of the extracted protein from the medium tissue of most organs was the worst. There were no significant differences in the concentrations of proteins extracted using the phenol, TCA or the modified TCA methods. These protein concentrations were lower than the protein concentrations extracted from the young plant tissues and higher than the protein concentrations extracted from the older tissues using the Tris and direct methods. The proteins obtained using the phenol extraction method had the widest range of molecular weights from $14 \mathrm{~Kb}$ to $116 \mathrm{~Kb}$; however, the TCA and modified TCA methods were inferior to the phenol method, while the Tris and direct methods were inferior to the TCA and modified TCA methods. The abovementioned results suggested that the Tris method should be the first choice for the extraction of barley seed proteins. The direct method was more suitable for the extraction of young and mature tissues. Moreover, the modified TCA method was suitable for tissue extraction from mature tissues, and the phenol method was superior to the other methods for the extraction of high molecular weight proteins. Thus, we have optimized easy and stable protein extraction methods for western blotting in barley.

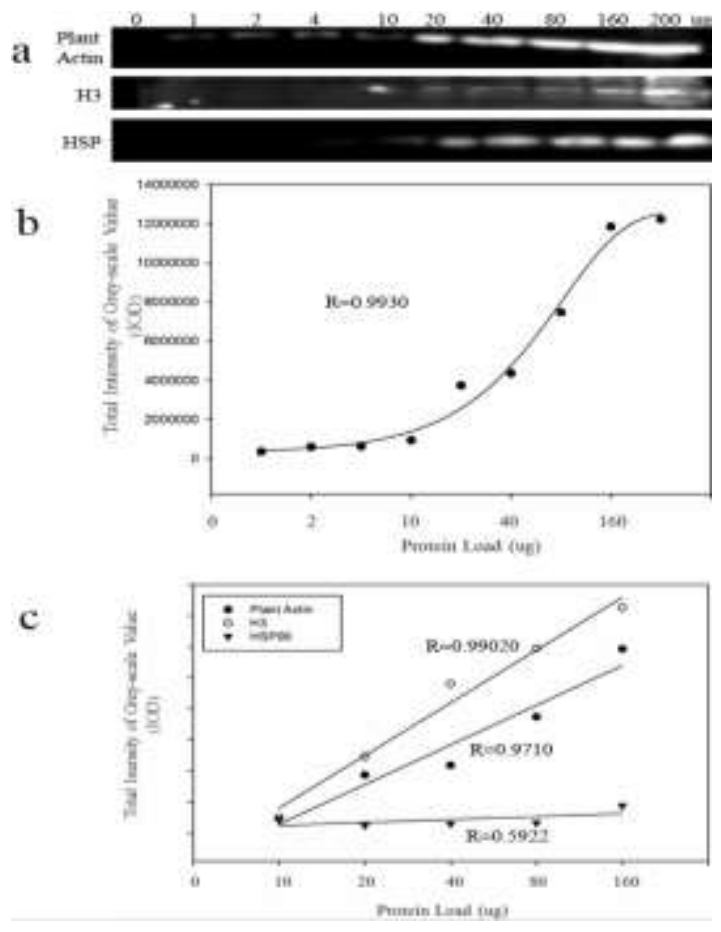

Fig. 3: Sensitivity comparison of the 3 internal reference proteins for barley western blotting. (a) Western blotting hybridization signals of the reference proteins. (b) Linear relationship between plant actin signal intensity and the quantity total protein loading. (c) Quantification analyses of the reference protein signal intensity vs. the quantity total protein loading

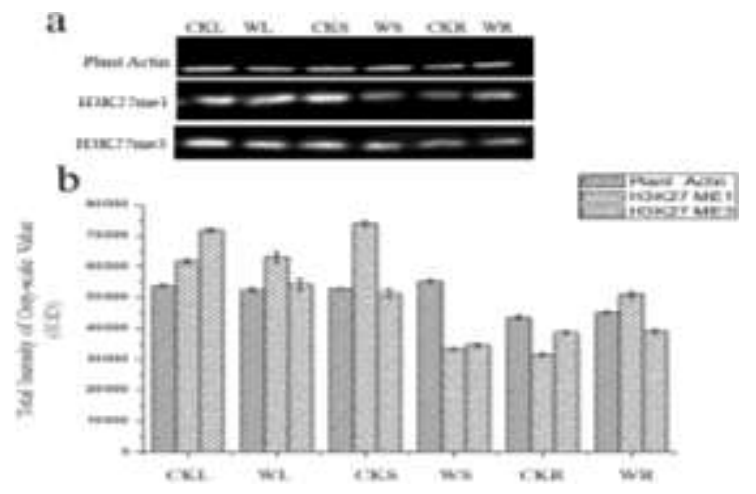

Fig. 4: Expression of the histone proteins H3K27me1 and H3K27me3 in barley different organs under waterlogging stress. (a) Western blotting signals of $\mathrm{H} 3 \mathrm{~K} 27 \mathrm{me} 1$ and H3K27me3 in barley different organs under waterlogging stress. (b) Relative expression of $\mathrm{H} 3 \mathrm{~K} 27 \mathrm{me} 1$ and $\mathrm{H} 3 \mathrm{~K} 27 \mathrm{me} 3$ via grey scale value analysis of the western blotting signals

\section{Suitable Reference Proteins for Barley Western Blotting}

Internal reference genes and proteins are essential for the quantitative assessment of the target gene and protein 
expression. Faccioli et al. (2007) showed that the Sadenosyl methionine decarboxylase gene, the HSP 90 gene, GAPDH, and TC139056 (which has an unknown function gene) could be the ideal fluorescence quantitative PCR internal reference genes for barley. Plant actin has been widely used as a fluorescence quantitative PCR internal reference gene in barley (Xu et al., 2017). Previous study has referred that HSP and eEF1- $\alpha$ were ideal internal reference proteins for western blotting in rice $(\mathrm{Li}$ et al., 2011). Thus far, there is no ideal internal reference protein for western blotting analysis in barley. Ideally, an internal reference gene should show continued stability in different tissues and a steady expression under different growth conditions (Li et al., 2011; Wu et al., 2014; Goasdoue et al., 2016). Moreover, the signal intensity of its corresponding protein should be linearly related to the amount of loading sample in a certain range (Ghosh et al., 2014; Chen and Xu, 2015; Bell, 2016). In this study, the comparison of the three internal proteins, i.e., plant actin, histone H3 and HSP 90, suggested that plant actin was stable and sensitive, and the western blot signal intensity showed a linear relationship with the amount of the loading sample in the range of 10-160 ng. Thus, plant actin, which is the ideal internal reference protein for western blotting in barley.

\section{H3K27 Methylation Modification in the Stress Response in Barley}

Previous studies indicated that $\mathrm{H} 3 \mathrm{~K} 27 \mathrm{me} 1$ is usually distributed in the heterochromatin region of the genome, while $\mathrm{H} 3 \mathrm{~K} 27 \mathrm{me} 3$ is distributed in the euchromatin region (Baker et al., 2015). However, these two types of modifications result in the inhibition of gene expression (Baker et al., 2015). H3K27me3 modification plays a key role in regulating plants by inhibiting the expression of the flowering gene FLC and controlling the expression of other genes in the spring-flowering channel/pathway (Yang et al., 2014) and regulate organ boundary formation (Cui et al., 2016). The H3K27me1 modification is widespread in the barley genome and is distributed intensively on the LTR retro-transposons (Baker et al., 2015). The results of this study showed that the H3K27me3 modification level in barley leaves was enhanced under waterlogging conditions, suggesting that the transcription of the euchromatin gene was inhibited. The level of H3K27me1 modification in the stem was decreased, which signalled the transcriptional activation of the reverse transcription factor in the heterochromatic region, but this activation was inhibited in the root system. These data indicated that the methylation of histone H3K27 was involved in the response to waterlogging in barley and had organ-specific response characteristics.

\section{Conclusion}

In this study, we identified the optimal total protein extraction method for different barley tissues and selected the suitable internal reference proteins for performing western blotting in barley. Using the improved barley western blotting platform established in this study, we discovered organs-specific expression changes in the histones H3K27me1 and H3K27me3 under waterlogging, which could provide a platform for future barley epigenetic studies.

\section{Acknowledgements}

This work was financially supported by the National Natural Science Foundation of China (31501309, 31201212), The Yangtze Youth Fund (2015cqt02, 2015cqr16) and Open found from Engineering Research Center of Ecology and Agriculture Use of Wetland, Ministry of Education, Yangtze University (KF201601).

\section{References}

Abdullah, F., L. Chua and Z. Rahmat, 2017. Comparison of protein extraction methods for the leaves of Ficus deltoidea. J. Fundam. Appl. Sci., 9: 908-924

Baker, K., T. Dhillon, I. Colas, N. Cook, I. Milne, L. Milne, M. Bayer and A.J. Flavell, 2015. Chromatin state analysis of the barley epigenome reveals a higher order structure defined by $\mathrm{H} 3 \mathrm{~K} 27 \mathrm{me} 1$ and H3K27me3 abundance. Plant J., 84: 111-124

Bass, J.J., D.J. Wilkinson, D. Rankin, B.E. Phillips, N.J. Szewczyk, K. Smith and P.J. Atherton, 2017. An overview of technical considerations for Western blotting applications to physiological research. Scand. J. Med. Sci. Sports, 27: 4-25

Bell, G., 2016. Quantifying western blots:None more black. BMCBiol., 14: 116 Blake, V.C., C. Birkett, D.E. Matthews, D.L. Hane, P. Bradbury and J.L. Jannink, 2016. The Triticeae toolbox: combining phenotype and genotype data to advance small-grains breeding. Plant Genom., 9: 110

Chen, W. and W.H. Xu, 2015. $\beta$-Actin as a loading control: Less than $2 \mu \mathrm{g}$ of total protein should be loaded. Electrophoresis, 36 2046-2049

Cui, X., F. Lu, Q. Qiu, B. Zhou, L. Gu, S. Zhang, Y. Kang, X. Cui, X. Ma and Q. Yao, 2016. REF6 recognizes a specific DNA sequence to demethylate H3K27me3 and regulate organ boundary formation in Arabidopsis. Nat. Genet., 48: 694-699

de San Celedonio, R.P., L.G. Abeledo and D.J. Miralles, 2014. Identifying the critical period for waterlogging on yield and its components in wheat and barley. Plant Soil, 378: 265-277

Eaton, S.L., M.L. Hurtado, K.J. Oldknow, L.C. Graham, T.W. Marchant, T.H. Gillingwater, C. Farquharson and T.M. Wishart, 2014. A guide to modern quantitative fluorescent western blotting with troubleshooting strategies. JoVE., 93: 52099

Egelhofer, T.A., A. Minoda, S. Klugman, K. Lee, P. Kolasinska-Zwierz, A.A. Alekseyenko, M.S. Cheung, D.S. Day, S. Gadel and A.A. Gorchakov, 2011. An assessment of histone-modification antibody quality. Nat. Struct. Mol. Biol., 18: 91-93

Faccioli, P., G.P. Ciceri, P. Provero, A.M. Stanca, C. Morcia and V. Terzi, 2007. A combined strategy of "in silico" transcriptome analysis and web search engine optimization allows an agile identification of reference genes suitable for normalization in gene expression studies. Plant Mol. Biol., 63: 679-688

Ghosh, R., J.E. Gilda and A.V. Gomes, 2014. The necessity of and strategies for improving confidence in the accuracy of western blots. Expert Rev. Proteomics, 11: 549-560

Goasdoue, K., D. Awabdy, S.T. Bjorkman and S. Miller, 2016. Standard loading controls are not reliable for western blot quantification across brain development or in pathological conditions. Electrophoresis, 37 : $630-634$ 
Guo, B., H. Luan, S. Lin, C. Lv, X. Zhang and R. Xu, 2016. Comparative proteomic analysis of two barley cultivars (Hordeum vulgare L.) with contrasting grain protein content. Front. Plant Sci., 7: 542

Hughes, A.J., D.P. Spelke, Z. Xu, C.C. Kang, D.V. Schaffer and A.E. Herr, 2014. Single-cell western blotting. Nat. Methods, 11: 749-755

Hurkman, W.J. and C.K. Tanaka, 1986. Solubilization of plant membrane proteins for analysis by two-dimensional gel electrophoresis. Plant Physiol., 81: 802-806

Jakob, S.S., D. Rödder, J.O. Engler, S. Shaaf, H. Özkan, F.R. Blattner and B. Kilian, 2014. Evolutionary history of wild barley (Hordeum vulgare subsp. spontaneum) analyzed using multilocus sequence data and paleodistribution modeling. Genom. Biol. Evol., 6: 685-702

Kinoshita, T. and M. Seki, 2014. Epigenetic memory for stress response and adaptation in plants. Plant Cell Physiol., 55: 1859-1863

Lämke, J. and I. Bäurle, 2017. Epigenetic and chromatin-based mechanisms in environmental stress adaptation and stress memory in plants. Genome Biol., 18: 124

Langridge, P., 2014. Reinventing the green revolution by harnessing crop mutant resources. Plant Physiol., 166: 1682-1683

Lai, Y., Y. Yu, X. Liu, H. Wan, Z. Zhang, L. Wang, Y. Leng, L. Ma, W. Yang and Z. Feng, 2017. Association mapping of grain weight, length and width in barley (Hordeum vulgare) breeding germplasm. Int. J. Agric. Biol., 19: 1175-1186

Li, X., H. Bai, X. Wang, L. Li, Y. Cao, J. Wei, Y. Liu, L. Liu, X. Gong and L. Wu, 2011. Identification and validation of rice reference proteins for western blotting. J. Exp. Bot., 62: 4763-4772

Mascher, M., H. Gundlach, A. Himmelbach, S. Beier, S.O. Twardziok, T. Wicker, V. Radchuk, C. Dockter, P.E. Hedley and J. Russell, 2017. A chromosome conformation capture ordered sequence of the barley genome. Nature, 544: 427-433

Mascher, M., T.A. Richmond, D.J. Gerhardt, A. Himmelbach, L. Clissold, D. Sampath, S. Ayling, B. Steuernagel, M. Pfeifer and M. D'ascenzo, 2013. Barley whole exome capture: a tool for genomic research in the genus Hordeum and beyond. Plant J., 76: 494-505

Ni, M., K. Dehesh, J.M. Tepperman and P.H. Quail, 1996. GT-2: In vivo transcriptional activation activity and definition of novel twin DNA binding domains with reciprocal target sequence selectivity. Plant Cell, 8: 1041-1059

Pan, L., G. Jinjie, Z. Yongfeng, Z. Liying, H. Yaqun and C. Jingtang, 2014. Epigenetic regulation during internode elongation of maize (Zea mays). Int. J. Agric. Biol., 16: 745-751

Pandey, G., N. Sharma, P. Pankaj Sahu and M. Prasad, 2016. Chromatinbased epigenetic regulation of plant abiotic stress response. Curr. Genomics, 17: 490-498

Saravanan, R.S. and J.K. Rose, 2004. A critical evaluation of sample extraction techniques for enhanced proteomic analysis of recalcitrant plant tissues. Proteomics, 4: 2522-2532
Setter, T. and I. Waters, 2003. Review of prospects for germplasm improvement for waterlogging tolerance in wheat, barley and oats. Plant Soil, 253: 1-34

Tsuji, H., H. Saika, N. Tsutsumi, A. Hirai and M. Nakazono, 2006. Dynamic and reversible changes in histone H3-Lys4 methylation and $\mathrm{H} 3$ acetylation occurring at submergence-inducible genes in rice. Plant Cell Physiol., 47: 995-1003

Vítámvás, P., M.O. Urban, Z. Škodáček, K. Kosová, I. Pitelková, J. Vítámvás, J. Renaut and I.T. Prášil, 2015. Quantitative analysis of proteome extracted from barley crowns grown under different drought conditions. Front. Plant Sci., 6: 479

Van Oosten, M.J., R.A. Bressan, J.K. Zhu, H.J. Bohnert and V. Chinnusamy, 2014. The role of the epigenome in gene expression control and the epimark changes in response to the environment. Crit. Rev. Plant Sci., 33: 64-87

Wang, W., R. Vignani, M. Scali and M. Cresti, 2006. A universal and rapid protocol for protein extraction from recalcitrant plant tissues for proteomic analysis. Electrophoresis, 27: 2782-2786

Wiśniewski, J.R. and M. Mann, 2016. A proteomics approach to the protein normalization problem: selection of unvarying proteins for MS-based proteomics and western blotting. J. Proteome Res., 15: 2321-2326

Wu, L., X. Hu, H. Tang, Z. Han and Y. Chen, 2014. Valid application of western blotting. Mol. Biol. Rep., 41: 3517-3520

Xu, Y., Q. Jia, G. Zhou, X.Q. Zhang, T. Angessa, S. Broughton, G. Yan, W. Zhang and $\mathrm{C}$. Li, 2017. Characterization of the $s d w 1$ semi-dwarf gene in barley. BMC Plant Biol., 17: 11

Yang, F., L. Zhang, J. Li, J. Huang, R. Wen, L. Ma, D. Zhou and L. Li, 2010. Trichostatin A and 5-azacytidine both cause an increase in global histone $\mathrm{H} 4$ acetylation and a decrease in global DNA and H3K9 methylation during mitosis in maize. BMC Plant Biol., 10: 178

Yang, H., M. Howard and C. Dean, 2014. Antagonistic roles for $\mathrm{H} 3 \mathrm{~K} 36 \mathrm{me} 3$ and $\mathrm{H} 3 \mathrm{~K} 27 \mathrm{me} 3$ in the cold-induced epigenetic switch at Arabidopsis FLC. Curr. Biol., 24: 1793-1797

Zhang, X., Y. Fan, S. Shabala, A. Koutoulis, L. Shabala, P. Johnson, H. Hu and M. Zhou, 2017. A new major-effect QTL for waterlogging tolerance in wild barley (H. spontaneum). Theor. Appl. Genet., 130: $1559-1568$

Zhang, X., S. Shabala, A. Koutoulis, L. Shabala, P. Johnson, D. Hayes, D. Nichols and M. Zhou, 2015. Waterlogging tolerance in barley is associated with faster aerenchyma formation in adventitious roots. Plant Soil, 394: 355-372

Zhou, M., 2011. Accurate phenotyping reveals better QTL for waterlogging tolerance in barley. Plant Breed., 130: 203-208

(Received 15 July 2017; Accepted 13 November 2017 